\title{
Ideias, práticas e instituições da medicina naval na origem da medicina tropical francesa
}

\section{Ideas, practices, and institutions in the field of naval medicine at the beginnings of French tropical medicine}

\author{
Matheus Alves Duarte da Silva \\ Doutorando, Centre Alexandre Koyré/École des Hautes Études en Sciences Sociales. \\ matheus.duarte@ehess.fr
}

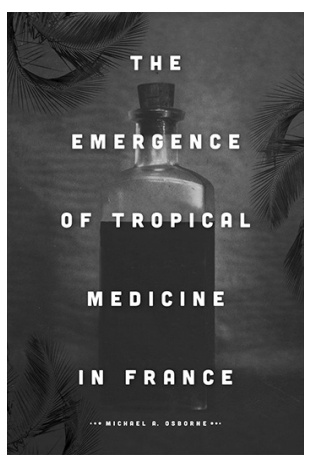

OSBORNE, Michael. The emergence of tropical medicine in France. Chicago: University of Chicago Press. 2014. 328p.
$\mathrm{O}$ mais recente livro de Michael Osborne, professor da Oregon State University, se interroga sobre a gênese e as características da medicina tropical francesa. A análise cobre o longo século XIX, da queda de Napoleão, em 1815, ao fim da Primeira Guerra Mundial, em 1918, período marcado pela constituição de um novo império colonial francês na Ásia e na África. O autor trabalha ao longo da obra com dois conjuntos de fontes. De um lado, aquelas provenientes da burocracia estatal, como as regulamentações que estruturaram e modificaram o ensino da medicina naval. De outro lado, as produzidas pelos médicos navais, como artigos, teses doutorais e manuais. O objetivo é, a partir da análise desses dois tipos de registros distintos, compreender as dinâmicas estabelecidas entre o sistema (system) e o ambiente diário (lifeworld) encontrado pelos médicos navais nas cidades portuárias. $\mathrm{O}$ autor defende que, contrariamente à teoria de Habermas, esses dois polos não estavam em conflito, no caso estudado no livro, mas em diálogo.

O argumento central da obra é que o "lugar" (place) desempenhou um papel preponderante na estruturação das ideias e das práticas da medicina tropical francesa. Osborne entende "lugar" para além do aspecto geográfico, como uma síntese entre o sistema e o ambiente diário, ressaltando, assim, seus aspectos simbólicos e sociais. Desse modo, o autor defende que a medicina tropical francesa é herdeira de uma tradição intelectual desenvolvida dentro de instituições da medicina naval situadas nas cidades portuárias de Brest, Rochefort-surmer, Bordeaux, Toulon e Marselha e, em menor escala, em Paris. Segundo Osborne, o sistema que estruturava essas instituições e o ambiente diário dessas cidades influenciaram e forneceram os meios para investigações originais dos médicos e das instituições de medicina naval ali baseadas. Dentre essas características locais, ressaltava-se a presença de prisioneiros (bagnes) - fontes para estudos psicológicos, raciais e anatômicos; navios - entendidos pelos médicos navais como espaços contingentes, com dinâmicas próprias na produção de doenças; marinheiros - que traziam em seus corpos doenças exóticas, como a malária e a 
febre amarela; e as relações comerciais dessas cidades com as colônias. Como exemplos das diversas controvérsias e pesquisas influenciadas por esse ambiente particular estavam a causa da cólica seca (dry collic), doença provocada pela presença de chumbo nos navios a vapor, e a existência, ou não, de efeitos energéticos advindos do consumo da noz-de-cola, produto importado da África.

A obra dialoga declaradamente com dois grupos de trabalhos historiográficos consagrados ao surgimento da medicina tropical na Europa. De maneira geral, com uma historiografia anglófona, quantitativamente maior, dedicada à medicina tropical inglesa e que demonstrou, sobretudo, que sua origem está relacionada a questões surgidas no Império Britânico, especialmente na Índia (Arnold, 1996; Harrison, 1994). Embora não discorde da interpretação para o caso inglês, Osborne entende que esse quadro explicativo não se aplica totalmente à França, posto que questões mais localizadas também influenciaram a constituição da medicina tropical francesa. De maneira mais específica, o autor discute com uma historiografia francesa centrada em arquivos parisienses e no Instituto Pasteur de Paris. Graças à escolha de trabalhar com outros arquivos e outras fontes, o autor constrói um enfoque mais plural, posto que centrado em cidades, instituições e personagens diferentes de Paris e de suas instituições. Mesmo no capítulo dedicado à capital, a análise não está voltada para o Instituto Pasteur, mas para a Faculdade de Medicina e para o professor Raphaël Blanchard, responsável pela institucionalização da parasitologia no país.

Apesar do título, Osborne utiliza ao longo de praticamente todo o texto os termos "medicina colonial" ou "medicina naval" e, somente nas últimas páginas, "medicina tropical", embora ressaltando que, no começo do século XX, os conceitos ainda se confundiam e que suas fronteiras eram pouco definidas (p.203). Ou seja, mais do que a emergência de uma entidade delimitada, a medicina tropical, o livro discute o surgimento e o desenvolvimento de uma medicina naval francesa interessada tanto nos assuntos comumente associados à medicina tropical, como as doenças encontradas no ultramar e transmitidas por vetores, quanto em problemas mais localizados. Entre eles, os citados exemplos de doenças surgidas nos navios e dos efeitos para a saúde do consumo de produtos advindos do império colonial francês.

Entretanto, uma questão pouco explorada no livro são as conexões entre a bacteriologia e a medicina naval. Conforme dito, no capítulo dedicado a Paris, o enfoque não está sobre o Instituto Pasteur. Todavia, diferentes médicos que assistiram ao curso de microbiologia do instituto e trabalharam em missões deste eram médicos navais, como Alexandre Yersin e PaulLouis Simond (Brossolet, Mollaret, 1993). Tendo isso em mente, e a partir da leitura do livro, seria possível questionar: de que forma a chamada, e contestada, "revolução pasteuriana" mudou ou influenciou as pesquisas da medicina naval? De que maneira a formação e a circulação de pesquisadores entre esses dois lugares, como no caso dos personagens citados acima, moldou as questões e a forma de realizarem suas investigações, tanto no aspecto teórico quanto na prática? O autor, por exemplo, destaca que Blanchard passou a maior parte da sua vida em Paris e que, por isso, necessitava do auxílio dos médicos navais para que coletassem e lhe enviassem espécimes de insetos, juntamente com observações sobre as doenças de climas tropicais. Porém, seria interessante ver discutida a outra face da moeda, isto é, como esses médicos que estavam na interseção da microbiologia e da medicina naval tiveram sua prática profissional nas colônias influenciada por esses dois espaços contingentes. 


\section{REFERÊNCIAS}

ARNOLD, David (Org.).

Warm climates and western medicine: the emergence of tropical medicine. Atlanta: Rodopi. 1996.

BROSSOLET, Jacqueline; MOLLARET, Henri. Alexandre Yersin, 1863-1943: un pasteurien en Indochine. Paris: Belin. 1993.
HARRISON, Mark.

Public health in British India: Anglo-indian preventive medicine, 1859-1914. Cambridge: Cambridge University Press. 1994.

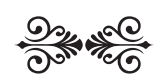

